\title{
EFFECTIVENESS OF ACTIVATED CARBON FROM COCONUT SHELL THROUGH POTASSIUM HYDROXIDE
}

\author{
ILHAM MUFANDi ${ }^{1}$, Siti JAMILATUN ${ }^{2 *}$, DWI ASTRI AYU PURNAMA ${ }^{3}$, \\ DAN RISKA UTAMI MELANI PUTRI ${ }^{4}$
}

\author{
${ }^{1}$ Department of Mechanical Engineering, Faculty of Engineering, Khon Kaen University, Thailand. \\ ${ }^{2}$ Program Studi Teknik Kimia, Fakultas Teknik Industri, Universitas Ahmad Dahlan, \\ Jalan Prof. Dr. Soepomo, SH., Janturan Umbulharjo, Yogyakarata. \\ ${ }^{3}$ Program Studi Teknik Kimia, Fakultas Teknik Industri, Universitas Ahmad Dahlan, \\ Jalan Prof. Dr. Soepomo, SH., Janturan Umbulharjo, Yogyakarata. \\ ${ }^{4}$ Program Studi Teknik Kimia, Fakultas Teknik Industri, Universitas Ahmad Dahlan, \\ Jalan Prof. Dr. Soepomo, SH., Janturan Umbulharjo, Yogyakarata. \\ *Correspondent Email: sitijamilatun@ che.uad.ac.id
}

\begin{abstract}
Article Information Abstract
Manuscript History : The aim of this work is to synthesis of activated carbon from pyrolysis of coconut shell Received on $06 \quad$ through $2 \mathrm{~N}$ potassium hydroxide $(\mathrm{KOH})$. Carbon can be produced from material through March 2020

Accepted after being revised on 27

December 2020

Published on 31

December 2020

Keywords: Activated Carbon; Pyrolysis; Catalyst. heating at high temperatures with a porous solid containing $85 \%-95 \%$. During the heating process, the carbon is only carbonized, and without oxidized in the heating chamber to avoid air leakage. Activated carbon can be used as an adsorbent. The absorption capacity of activated carbon is determined by the surface area of the particles. The absorption ability of activated carbon can be improved through an activation with chemicals such as $\mathrm{KOH}$. Carbon will change in physical and chemical properties. This research used the pyrolysis process at an operating temperature of $550{ }^{\circ} \mathrm{C}$. There were three stages of active carbon production by activating $\mathrm{KOH}$, namely 1) immersion of coconut shell through $2 \mathrm{~N} \mathrm{KOH}$ with a variable time of 5 days, 2) drying process of coconut shell in sunlight, 3) the burning process of dry coconut shell with the temperature of $500^{\circ} \mathrm{C}$, and 4) the $\mathrm{KOH}$ activation process by reabsorbing activated carbon using $\mathrm{KOH}$ and drying in the sun. The results indicated that the water content of activated carbon was affected by drying time. The testing of the activated carbon water content shows that the quality of activated carbon meets Indonesian Standards (SNI, 1995), which is less than $15 \%$. According to Indonesian Industrial Standard (SII) No.0258-79, the ash content of activated carbon is $2.5 \%$, While the result in this study is exceeded $2.5 \%$.
\end{abstract}

\section{INTRODUCTION}

Activated carbon has many benefits, including: (i) in the food industry as a color deodorant, and deodorizing, (ii) to breakdown the heavy metal ad organic compounds from liquids, (iii) food processing and water de-chlorination, (iv) to adsorption of hazardous chemicals and drugs in medical fields, and (v) to gas cleaning in air filters in general and in the industry [1], [2]. The making of activated carbon can be done with pyrolysis technology [3]-[5]. Pyrolysis is the process of heating a substance without oxygen with resulting in the decomposition of hardwood components. The product of this pyrolysis process is liquid, gas, and solid [6]-[8]. The solid product from this process is char, which is then called carbonization [9]. Biomass carbonization or better known as combining is a process to increase the calorific value of biomass and produce clean combustion with little smoke. The results of carbonization are in the form of carbon composed of carbon and black. The general process to synthesis carbon is through physical or thermal and chemical activation [10]. There are the applications of activated carbon to remove chemical properties: $\mathrm{Hg}$ (II) in aqueous [11], $\mathrm{H}_{2} \mathrm{~S}$ adsorption [12], and also can be used for water treatment [13] and to reduce of biological oxygen demand (BOD) and chemical oxygen demand (COD) [14].

Activation of activated carbon can be done using homogeneous catalysts and heterogeneous catalysts. Homogeneous catalysts are catalysts with the same phase as reactants and products, while heterogeneous catalysts are different phases as reactants and products [15]. Potassium hydroxide $(\mathrm{KOH})$ and sodium hydroxide $(\mathrm{NaOH})$ are the alkoxides that used the activated carbon in homogeneous catalysts [16]. This activation process aims to increase the surface area ranging 
from 300 to $3500 \mathrm{~m}^{2} / \mathrm{g}$ to become a good absorbent [17]. The synthesis of activated carbon can be distributed in one step and two steps by using chemical [18], [19].

Absorption of activated carbon is very large, i.e. $1 / 4$ to 10 times the weight of activated carbon. Activated carbon is a good adsorbent for the adsorption of liquids, liquids, and solutions. The quality of activated carbon is indicated by the value of IOD absorption, which is based on the provisions of SNI 06-3730-1995. Active carbon is rated as quality when the absorption value of IOD is close to $750 \mathrm{mg} / \mathrm{g}$ [8]. The most suitable application in carbon is physical properties, for example, abrasion resistance or hardness of activated carbon. The specific gravity characteristics can also be a major consideration for specific applications [20]. The important characteristic of activated carbon is Iodine value, it can describe the size of the micropore volume and the total internal surface area. Ash content can describe the purity of activated carbon [21].

This study aims to make activated carbon from coconut shells by activation using a $\mathrm{KOH}$ catalyst. The coconut shell used is soaked first using $\mathrm{KOH}$ with a combustion temperature of 550 ${ }^{\circ} \mathrm{C}$. The carbon obtained from the pyrolysis process while the activated carbon by using $\mathrm{KOH} 2 \mathrm{~N}$ and tested the water content, ash content, and iodine number.

\section{MATERIALS AND METHODS}

\section{Materials}

Coconut shells as the main raw material in this study were obtained from coconut sellers in Yogyakarta Giwangan Market. Besides, the catalyst used is potassium hydroxide $(\mathrm{KOH})$, which was obtained from the Ahmad Dahlan University Process Unit Laboratory, Yogyakarta. Coconut shells were crushed using a stone crusher to facilitate the combustion process in the furnace.

\section{Methods}

Coconut shells were immersed by using potassium hydroxide $(\mathrm{KOH})$ with a variation of 5 days, then the pyrolysis process is carried out with a temperature of $550{ }^{\circ} \mathrm{C}$ can be seen in Figure 1. Active carbon obtained from the pyrolysis process was then reactivated using $\mathrm{KOH}$ and then testing the water content, ash content, and iodine number.

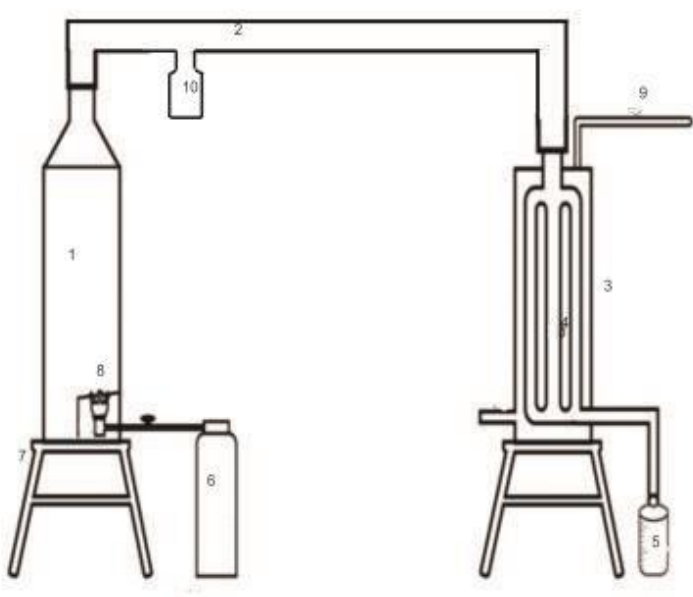

Figure 1. Experiment equipment.

Where:
1. Reactor
6. LPG
2. Vapor pipe
7. Stand
3. Condenser
8. Incinerator
4. Tubular pipe
9. Valve water
5. product storage
10. Thermocouple

Water content test was carried out by weighing $1 \mathrm{~g}$ of activated carbon and then roasting it at a temperature from 105 to $110{ }^{\circ} \mathrm{C}$ and allowed to stand for about 120 minutes. Then activated carbon was weighed for 1 gram and heated in the furnace with a temperature of $815{ }^{\circ} \mathrm{C}$ for approximately 120 minutes. The IOD number test is carried out through a titration process using 0.1 $\mathrm{N}$ sodium thiosulfate with an indicator of $1 \%$ amylum solution.

\section{RESULTS AND DISCUSSIONS}

\section{Relationship between Levels of Activated Carbon Iodine and Immersion Variations}

Determination of absorption of active carbon against iodine is a general requirement for assessing the quality of activated carbon. Based on Indonesian Standards (SNI, 1995) states that the absorption capacity of activated carbon iodine ranges from $359.5 \%-1050.5 \%$. Figure 2 shows the relationship between iodine levels and activation time in activated carbon with variations in immersion time. From these results, it is known that the absorption rate of the sample iodine is influenced by the time of sample activation. At the time of activation for 5 days, the absorbance of activated carbon iodine successfully was 266.49; $304.56 ; 368.01 ; 393.39 ; 482.22 \mathrm{mg} \mathrm{IOD} / \mathrm{g}$ carbon.

Based on the analysis results, it was found that the activation treatment of the sample was very influential on the absorption of activated carbon iodine. This means that the longer the activation 
time, the higher the level of iodine absorption ( $\mathrm{mg}$ IOD/g charcoal) obtained. Hence, the higher the absorption rate of iodine from activated carbon, the better it is used as an adsorbent.

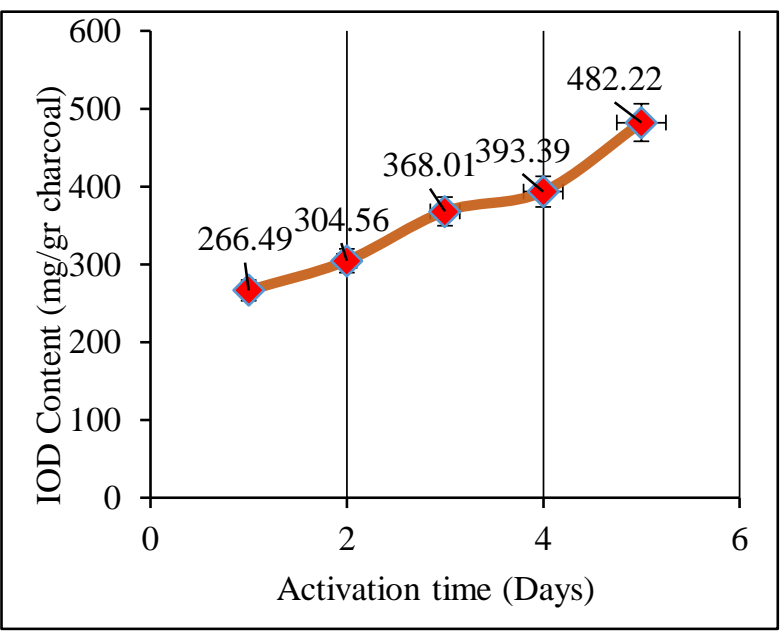

Figure 2. Relationship between iodine levels and activation times (days).

\section{The Relationship between Water Content in Activated Carbon and Variations in Immersion Time}

Determination of water content of activated carbon aims to determine the hygroscopic properties of activated carbon. The calculation of the water content of activated carbon is based on the dry weight of the activated carbon in the oven. The value that meets the Indonesian Standard requirements (SNI, 1995) that shows in Table 1. This is due to the hygroscopic activator which can reduce the water content. Figure 3 shows the water content on $\mathrm{KOH}$ activation with a variation of immersion time 5 days before and after pyrolysis. From the results of this research, it can be seen that the sample water content is affected by sample concentration and sample activation time. In the variation of immersion time, the water content of activated carbon was $18 \% ; 16 \% ; 15 \% ; 19 \%$; $9 \%$. Based on the above analysis, it was found that the immersion time on the sample did not affect the results of the water content obtained. However, the result of the water content is influenced by the activated carbon drying time. The longer the drying, the less water content in the carbon. Thus, the lower the water content in the carbon sample, the better the activated carbon is used.

Table 1. Indonesia standars (SNI, 1995) of activated carbon

\begin{tabular}{cc}
\hline Items & Values \\
\hline Water content $(\%)$ & Maks. 15 \\
Ash content $(\%)$ & Maks. 10 \\
\hline
\end{tabular}

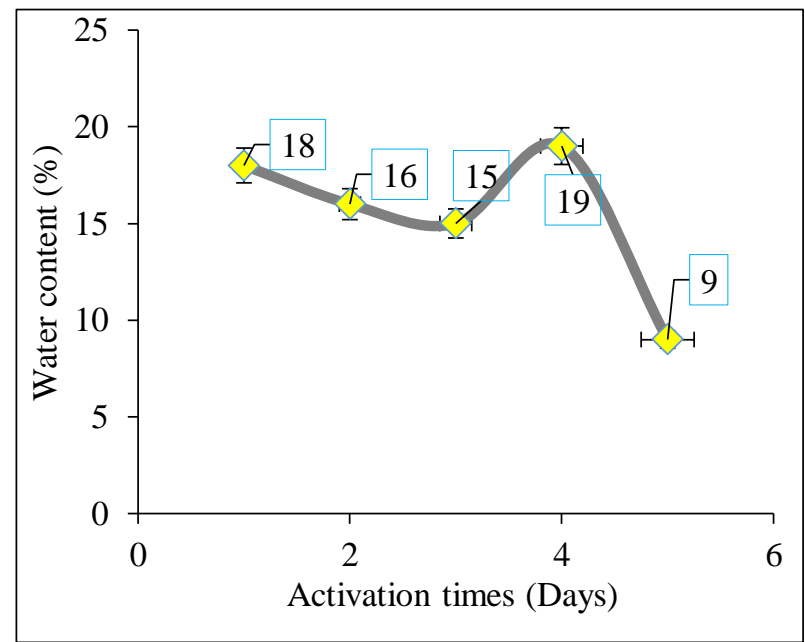

Figure 3. Relationship of water content on $\mathrm{KOH}$ activation with immersion time 3 days before and after pyrolysis.

\section{The Relationship between Ash Content in Active Carbon and Soaking Time Variation}

The testing of ash content is to determine the content of metal oxides in activated carbon. Activating chemicals affect the ash content of activated carbon. This statement is based on an analysis that shows that the activation concentration and activation treatment have a significant effect on the level of activated carbon ash. This is because the cause of high levels of activated carbon ash is due to oxidation processes. The amount of ash content can affect the absorption of activated carbon that described in Figure 4, both gas and solution because the mineral content contained in ash such as calcium, potassium, magnesium, and sodium will spread in the grid.

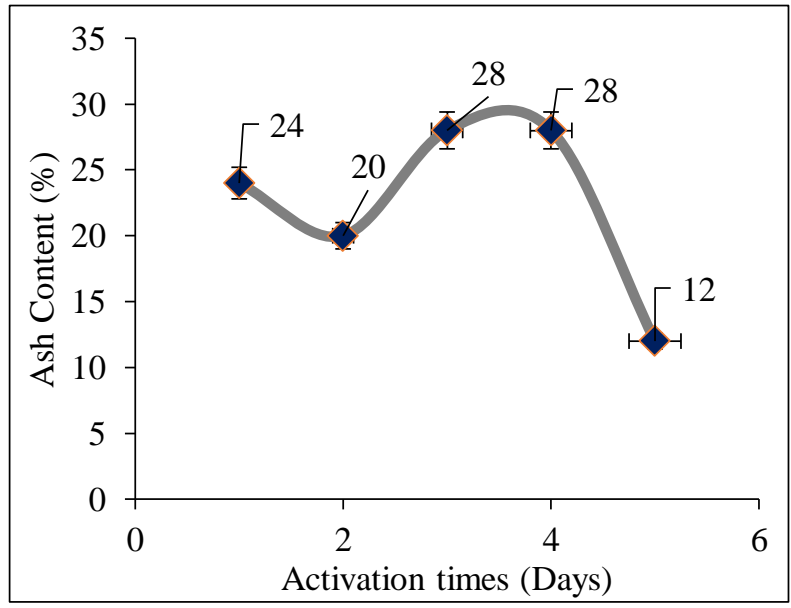

Figure 4. Relationship of ash content on $\mathrm{KOH}$ activation with immersion time 5 days before and after pyrolysis.

From the figure above it can be described that the ash content of the sample is affected by the sample concentration and sample activation time. 
In the variation of immersion time, the water content of activated carbon was $24 \% ; 20 \% ; 28 \%$; $28 \% ; 12 \%$. According to SII No.0258-79 that described in Table 2 . While the results of this study, the results exceeded $2.5 \%$. this is caused by the high oxygen content at the time of combustion.

Table 2. Industry Indonesia Standars (SII No.0258-79) of activated carbon

\begin{tabular}{cc}
\hline Items & Values \\
\hline Water content $(\%)$ & Maks. 10 \\
Ash content $(\%)$ & Maks. 2.5 \\
\hline
\end{tabular}

\section{CONCLUSIONS}

The results of the study can be concluded that the level of iodine obtained ranging from 266 to 500 $\mathrm{mg} \mathrm{I} / \mathrm{g}$ carbon, the water content obtained ranges from 10 to $15 \%$ with activation for 5 days, ash content obtained ranging from 8 to $30 \%$ with activation for 5 days, water content and ash content are not affected by concentration and activation time.

\section{ACKNOWLEDGMENT}

Researchers would like to thank research funding assistance through the Internal Grant Competitive Research Grant scheme through the Research and Community Service Institute of Ahmad Dahlan University, Yogyakarta.

\section{REFERENCES}

[1] Y.S. Jeong, K. B. Park, and J. S. Kim, "Hydrogen production from steam gasification of polyethylene using a two-stage gasifier and active carbon", Applied Energy, vol. 262, pp. 114495, 2020.

[2] T.A. Buscheck, T.R. Elliot, M.A. Celia, M. Chen, Y. Sun et al., "Integrated geothermal $\mathrm{CO}_{2}$ reservoir systems: Reducing carbon intensity through sustainable energy production and secure $\mathrm{CO}_{2}$ storage", Energy Procedia, vol. 37, pp. 6587-6594, 2013.

[3] A.V. Bridgwater, "Renewable fuels and chemicals by thermal processing of biomass", Chemical Engineering Journal, vol. 91, no. 23, pp. 87-102, 2003.

[4] W. Treedet, R. Suntivarakorn, I. Mufandi, and P. Singbua, "Bio-oil production from Napier grass using a pyrolysis process: Comparison of energy conversion and production cost between bio-oil and other biofuels. International", Energy Journal. vol. 20, no. 2, pp. 155-168, 2020.

[5] J. L. Zheng, "Pyrolysis oil from fast pyrolysis of maize stalk", Journal of Analysis Applied Pyrolysis, vol. 83, no. 2, pp. 205-212, 2008.

[6] I. Mufandi, W. Treede, P. Singbua, and R. Suntivarakorn, "The Comparison of Bio-oil Production from Sugarcane Trash, Napier Grass, and Rubber Tree in The Circulating Fluidized Bed Reactor", TEST Engineering and Management. Journal, vol. 82, no. 4557, pp. 4557-4563, 2020.

[7] P. Adams, T. Bridgwater, A. Lea-Langton, A. Ross, and I. Watson. Biomass Conversion Technologies. Report to NNFCC. Elsevier Inc., 2017.

[8] C. Dalai, R. Jha, and V. R. Desai, "Rice Husk and Sugarcane Baggage Based Activated Carbon for Iron and Manganese Removal", Aquat Procedia, vol. 4, pp. 1126-1133, 2015.

[9] N. L. Panwar, R. Kothari, and V. V. Tyagi. "Thermochemical conversion of biomass Eco-friendly energy routes", Renewable Sustainable Energy Reviews, vol. 16, no. 4 pp. 1801-1816, 2012.

[10] P. T. Williams, "Pyrolysis of waste tires: A review", Waste Management, vol. 33, no. 8, pp. 1714-1728, 2013.

[11] Z. Liu, Y. Sun, X. Xu, X. Meng, J. Qu et al., "Preparation, characterization and application of activated carbon from corncob by $\mathrm{KOH}$ activation for removal of $\mathrm{Hg}$ (II) from aqueous solution", Bioresource Technology, vol. 306, no. 1, 123-154, 2020.

[12] S. Wang, H. Nam, and H. Nam, "Preparation of activated carbon from peanut shell with $\mathrm{KOH}$ activation and its application for $\mathrm{H}_{2} \mathrm{~S}$ adsorption in confined space", Journal of Environmental Chemical Engineering, vol. 8, no. 2, 103683, 2020.

[13] S. Jayanti and N. K. Sumarni, "Kajian Arang Aktif Biji Asam Jawa (Tamarindus Indica Linn) Menggunakan Aktivator H3PO4 Pada Penyerapan Logam Timbal", Jurnal Riset Kimia, vol. 1, no. 1, pp. 13-19, 2015.

[14] I. Suyata, "Optimasi Penurunan Nilai BOD, COD, dan TSS Limbah Cair Industri Tapioka Menggunakan Arang Aktif dari Ampas Kopi", Jurnal Molekul, vol. 5, no. 5, pp. 22-23. 2010.

[15] A.V. Bridgwater, D. Meier, and D. Radlein, "An overview of fast pyrolysis of biomass", Geochemical, vol. 30, no. 12, pp. 1479-1493, 1999.

[16] Q. Liang, Y. Liu, M. Chen, L. Ma, B. Yang et al., "Optimized preparation of activated carbon from coconut shell and municipal sludge", Material Chemical Physic, vol. 241, 122327, 2019.

[17] D. Angin, "Effect of pyrolysis temperature and heating rate on biochar obtained from 
pyrolysis of safflower seed press cake", Bioresour Technology, vol. 128, pp. 593-597, 2013.

[18] O. Oginni, K. Singh, G. Oporto, B. DawsonAndoh, L. McDonald, and E. Sabolsky, "Influence of one-step and two-step $\mathrm{KOH}$ activation on activated carbon characteristics", Bioresour Technology Reports, vol. 8, 100307, 2019.

[19] E. M. Mistar, T. Alfatah, and M. D. Supardan, "Synthesis and characterization of activated carbon from Bambusa vulgaris striata using two-step KOH activation", Journal Material. Research and Technology, vol. 9, no. 3, pp. 6278-6286, 2020.
[20] G. Ravenni, O. H. Elhami, J. Ahrenfeldt, U. B. Henriksen, and Y. Neubauer, "Adsorption and decomposition of tar model compounds over the surface of gasification char and active carbon within the temperature range 250$800^{\circ} \mathrm{C} "$, Applied Energy, vol. 241, pp. 139151,2019

[21] S. Huang, S. Wu, Y. Wu, and J. Gao. "Structure characteristics and gasification activity of residual carbon from updraft fixedbed biomass gasification ash", Energy Conversion and Management, vol. 136, no. 12, pp. 108-118, 2016. 